https://doi.org/10.48009/1_iis_2006_3-7

\title{
MEASURING GROWTH AND IMPACT: ETHICAL REASONING IN THE INFORMATION SYSTEMS TECHNOLOGY FIELD
}

\author{
Belle S. Woodward, Southern Illinois University, bellew@siu.edu \\ Susanne Ashby, Southern Illinois University, susanneashby@aol.com
}

\begin{abstract}
Heightened by emerging web-based technologies through which it has become easier for anyone to engage in illegal or unethical appropriation and use another's personal information, the debate is ongoing concerning how best to teach ethics in order to maximize its impact on learners. Currently, ethics is taught through a variety of methods using various resources. This quasi-experimental study examined the effects of ethics instruction on learning and moral development with information technology undergraduate students $(N=32)$ at a Midwest university. Researchers analyzed two groups: one exposed to ethics instruction through the use of case studies and the control group which did not receive direct ethics instruction in this repeated-measures design. Participants were tested using the Defining Issues Test (DIT-2) and results were analyzed using an analysis of covariance. Results demonstrated no statistically significant difference, thus indicating no difference between groups provided ethics training using case study method versus groups provided no instruction in ethics.
\end{abstract}

Keywords: Case Method, Information Security Ethics, Content Delivery, Instructional Method, Assessment

\section{INTRODUCTION}

Over the last generation, advances in technology have dramatically reshaped the workplace and have impacted society in general. With these rapid-fire changes, the need for ethical behavior by individuals dealing with technology is paramount. This is evidenced in a statement made by financial advisor Bernard Baruch, who during his lifetime had "witnessed a whole succession of technological revolutions, but none of them has done away with the need for character in the individual or the ability to think" [5, p. 130]. No matter how much computers and technology advance, it will always be essential to emphasize the importance of sound ethical reasoning in students of all ages.

\section{Concerns within the IT Industry}

For many years, the Association of Computing Machinery [1] has emphasized the need for individuals to understand the basic cultural, social, legal, and ethical issues required in computing. However, the focus of coursework in most higher education institutions as well as most company trainings is not on these critical issues. This is made evident by their limited budget lines for employee training as opposed to technical expenditures spent on systems needed to respond to intrusions. This was noted by Hillier [6]: "North American enterprises spend billions of dollars each year on IT security software, hardware, programs, and services that do little more than react to security problems."

This venue of employee training and awareness that is receiving the least amount of attention is exactly where ethics needs to be incorporated. Future computer users and especially security specialists need to be made aware that they too have a major responsibility to security maintenance, and that there are consequences of unethical behavior. One place to start producing ethically competent and morally confident information systems professionals is to develop a comprehensive program at the undergraduate level that addresses ethical decisionmaking especially in regard to information systems and security. Although schools, universities, and government agencies have developed curricula using specific instructional interventions for information systems and information security, it is not readily apparent which of these instructional interventions provide the most satisfactory result. Neither is it apparent which aspect of the curricula significantly increases and maintains ethical behavior in students over time.

\section{REVIEW OF LITERATURE}

The last decade has seen a surge of research devoted to the development of ethics programs across the science, technology, engineering, and mathematics disciplines at the college level. These programs have employed various configurations of ethics and course content as well as the use of various instructional methodologies. The results of these studies are 
anecdotal and rather inconclusive as to clearly delineating the most influential factors of the treatments.

Several studies have been conducted with conflicting results in the area of assessing ethics education in engineering and information systems. Earlier research by Self and Ellison [12] used the Defining Issues Test (DIT) to measure the increase, if any, in moral reasoning induced by the enrollment in an engineering ethics course. A pre/post test design of ethical reasoning and development (DIT) was used, and comparisons were done to relate the scores. Their findings showed that the ethics education had a significant impact on the test scores. They concluded that the differences in test scores could be attributed to the training received in the course. However, since no control group was used to verify that external factors were not at play, the conclusions cannot be considered representative of actual changes in moral development.

Drake et al. [4] found that the methods for including ethics education in engineering still had much room for improvement. Their study used two groups of university undergraduate students enrolled in an engineering program. One group was assigned to a full semester course on ethics, while the other group received ethics instruction as a component of an engineering course (an ethics module). These researchers measured the effect of an ethics education course using scores derived from the DIT-2, a revised version of the DIT. The researchers performed a t-test with equal variance to test for differences between groups on measures such as the $\mathrm{P}, \mathrm{N} 2$, and Type scores. They next tested for significance of correlation $(\alpha=.05)$ using a Pearson correlation coefficient. The researchers found that the module approach used did not show any improvement of moral reasoning. Also, when the module treatment group's mean scores were compared to the semesterlength ethics course, no significant difference between the groups was found. Measure of effect size for both groups suggested that a full semester course on ethics had a small effect. Researchers concluded that when pre- and post test scores for both groups were compared using a $t$-test, improvements were more likely due to the students' familiarity with the test and not a result of ethical instruction.

In a study conducted by Owens [8], a significant difference in the pre-/post test scores of 16 participants was found. These undergraduate students were enrolled in Southwestern University's First Year Seminar Program emphasizing ethical analysis. The program provided ethics instruction using an
Internet course with an ethics component, yet did not use a control group for comparison. Coupled with a small sample size, this study offers little conclusive evidence.

There have been numerous empirical studies that have revealed a relationship between ethical reasoning/moral judgment and evaluation of ethical dilemmas. The Defining Issues Test or DIT [11] is a validated measure for ethical reasoning. Thirty years of testing with the DIT-2 has established its validity and reliability and, most importantly for our study, it has proven to be particularly sensitive to the effects of educational interventions. Although the DIT-2 was developed to measure general moral development, it has been found to measure overall moral development in many types of educational programs including medicine, business, and law among others.

\section{METHODOLOGY}

This quasi-experimental study examined the effects of ethics instruction on undergraduate students' learning and moral development in an undergraduate information systems and applied technologies course. The treatment group received four weeks of ethics instruction using the case method approach in a course entitled Ethics and Information Security. This course was designed specifically to address ethics and security issues in information technology. Students were enrolled during the Fall 2005 semester. The class met in a small lecture section on Tuesdays and Thursdays for 16 weeks. The materials for the course were drawn primarily from recent security breaches relayed in the news media. The class focused on developing students' skills in analyzing cases, generating a range of possible solutions, and building an argument for their preferred solutions. Additional weekly writing assignments, essays, and a final exam in essay format were also based on the case studies.

The control group for this study received the more traditional instruction method featuring lecturediscussion. The course topics primarily concerned information security without an emphasis on ethical considerations.

The sample $(\mathrm{N}=32)$ was drawn from a pool of 105 undergraduate students enrolled in the Informational Technology program offered at a Midwestern university. Students in the treatment group $(n=16)$ were self-selected by enrolling in the aforementioned course. As random assignment was not possible, each member of the treatment group was matched with a participant from the control group. Participants were 
matched according to age and gender. Two of the sixteen treatment students were purged on consistency checks while one student did not complete the course. This situation resulted in 13 pre/post test matched pairs being available for subsequent analysis.

Using a repeated-measures design, participants were given pre-tests prior to commencing with the coursework and then retested at the end of the semester. The instrument used was the Defining Issues Test (DIT-2). The DIT-2 is a test of moral reasoning founded upon Kohlberg's cognitive developmental premise of moral development [10]. The most influential research focusing on moral development in student populations is by Lawrence Kohlberg [7]. Kohlberg's work is particularly relevant for thinking about undergraduate students because it combines cognitive and moral development. In Kohlberg's model, the development of ethical behaviors relies on a learning process; growth in cognitive development creates a "state of readiness" necessary for moral development [14]. Kohlberg's model progresses through six stages; the six stages are embedded within three levels (preconventional, conventional, and post-conventional). The six stages which cover higher and lower level stage reasoning document a person's evolution from highly egocentric concerns (including decisions based on the avoidance of punishment), through a stage of making decisions based on what others expect or rules require, to a view of morality based on universal principles such as equality and human rights. In this way, Kohlberg's work focuses on morality as an understanding of (and acting upon) social rights and rules.

The DIT-2 consists of five scenarios involving ethical situations. Participants are required to choose between twelve responses that embody statements used to represent stages of moral development identified by Kohlberg. Participants are next asked to rank the importance of each question in making a decision, tell what their decision is, and then rank the four most important questions. This process yields a $\mathrm{P}$ score. The $\mathrm{P}$ score indicates the occurrence of postconventional thinking on the part of each subject. This is given as a percentage from 0 to 95 . It is calculated by summing the scores from test answers corresponding to Stages 5 and 6 of Kohlberg's scale, and then converting those scores to a percentage. In developing the DIT-2, Rest and his collaborators have also developed a DIT index score: N2. A key feature of this index is that higher stage reasoning is prioritized and lower stage reasoning is rejected $[11,10]$. The test accounts not only for ranked items that reflect post-conventional moral reasoning, but also for rated items reflecting respondents' preferences for higher versus lower stage reasoning.

Based upon the work of Rest, Thoma, Narvaez, and Bebeau [11], the following indexes were used to score moral judgment: post-conventional index (P); and higher stage discriminating index (N2). The postconventional $(\mathrm{P})$ index represents the degree to which a participant attributes importance to principled or post-conventional moral thinking (Kohlberg's stages 5 and 6). The greater the $\mathrm{P}$ score, the greater the use of post-conventional thinking is being represented. The $\mathrm{P}$ score measures how strongly the subject uses post-conventional moral reasoning [10].

The N2 index is the new index derived from the reformulation of the DIT-2. The N2 score incorporates both the subject's preference for higher stage reasoning (Stages 5 and 6 ) and the subject's rejection of lower stage reasoning (Stages 2 and 3). Thus, the scale measures how discriminating a respondent is between choosing low and high stages by determining how consistently the respondent selects one stage and rejects the other. Rating data is weighted in order for the $\mathrm{N} 2$ score to have the same mean and standard deviations as the P score, allowing for comparisons to be made.

\section{RESULTS}

Analysis of covariance was performed to examine if the difference in post test scores between groups was statistically significant after controlling for the difference in pretest scores. Means and standard deviations are displayed in Tables 1 and 2.

Table 1. DIT2 Pre and Post Course P Scores Postconventional (Stage 5)

\begin{tabular}{|l|l|l|l|}
\hline Group & & $\begin{array}{l}\text { Pretest } \\
\text { (P Score) }\end{array}$ & $\begin{array}{l}\text { Post test } \\
\text { (P Score) }\end{array}$ \\
\hline Control & Mean & 28.0573 & 28.8434 \\
\hline & N & 13 & 13 \\
\hline & $\begin{array}{l}\text { Std. } \\
\text { Deviation }\end{array}$ & 11.03944 & 13.28047 \\
\hline Treatment & Mean & 30.3077 & 29.5974 \\
\hline & N & 13 & 13 \\
\hline & $\begin{array}{l}\text { Std. } \\
\text { Deviation }\end{array}$ & 13.48694 & 17.71747 \\
\hline Total & Mean & 29.1825 & 29.2204 \\
\hline & N & 26 & 26 \\
\hline & $\begin{array}{l}\text { Std. } \\
\text { Deviation }\end{array}$ & 12.12950 & 15.34542 \\
\hline
\end{tabular}


Table 2. DIT2 Pre and Post Course N2 Scores

\begin{tabular}{|l|l|l|l|}
\hline Group & & $\begin{array}{l}\text { Pretest } \\
\text { N2 Score }\end{array}$ & $\begin{array}{l}\text { Post test } \\
\text { N2 Score }\end{array}$ \\
\hline Control & Mean & 26.8271 & 30.9484 \\
\hline & N & 13 & 13 \\
\hline & $\begin{array}{l}\text { Std. } \\
\text { Deviation }\end{array}$ & 13.54216 & 12.32024 \\
\hline Treatment & Mean & 25.0522 & 25.3500 \\
\hline & N & 13 & 13 \\
\hline & $\begin{array}{l}\text { Std. } \\
\text { Deviation }\end{array}$ & 13.78517 & 16.14674 \\
\hline Total & Mean & 25.9397 & 28.1492 \\
\hline & N & 26 & 26 \\
\hline & $\begin{array}{l}\text { Std. } \\
\text { Deviation }\end{array}$ & 13.41869 & 14.35797 \\
\hline
\end{tabular}

The ANCOVA result indicates that there is no group difference in both DIT-2 P score $(F=0.033, p=0.857)$ and $\mathrm{N} 2$ score $(F=1.092, p=0.307)$ at the post test session (See Table 3 and 4 ).

\section{Tests of Between-Subjects Effects}

Table 3. Dependent Variable: Post test Post Conventional (P score)

\begin{tabular}{|l|l|l|l|l|l|}
\hline Source & $\begin{array}{l}\text { Type III } \\
\text { Sum } \\
\text { of } \\
\text { Squares }\end{array}$ & df & $\begin{array}{l}\text { Mean } \\
\text { Square }\end{array}$ & F & Sig. \\
\hline $\begin{array}{l}\text { Corrected } \\
\text { Model }\end{array}$ & $2042.197 \mathrm{a}$ & 2 & 1021.098 & 6.108 & .007 \\
\hline Intercept & 201.109 & 1 & 201.109 & 1.203 & .284 \\
\hline PSCORE & 2038.502 & 1 & 2038.502 & 12.194 & .002 \\
\hline GROUP & 5.559 & 1 & 5.559 & .033 & .857 \\
\hline Error & 3844.853 & 23 & 167.168 & & \\
\hline Total & 28086.699 & 26 & & & \\
\hline $\begin{array}{l}\text { Corrected } \\
\text { Total }\end{array}$ & 5887.050 & 25 & & & \\
\hline a. R Squared $=.347$ (Adjusted R Squared =.290) \\
\hline
\end{tabular}

Tests of Between-Subjects Effects

Table 4. Dependent Variable: Post test N2

\begin{tabular}{|l|l|l|l|l|l|}
\hline Source & $\begin{array}{l}\text { Type III } \\
\text { Sum } \\
\text { of } \\
\text { Squares }\end{array}$ & df & $\begin{array}{l}\text { Mean } \\
\text { Square }\end{array}$ & F & Sig. \\
\hline $\begin{array}{l}\text { Corrected } \\
\text { Model }\end{array}$ & $2649.947 \mathrm{a}$ & 2 & 1324.974 & 12.171 & .000 \\
\hline Intercept & 427.871 & 1 & 427.871 & 3.930 & .059 \\
\hline PSCORE & 2446.230 & 1 & 2446.230 & 22.471 & .000 \\
\hline GROUP & 118.909 & 1 & 118.909 & 1.092 &. .307 \\
\hline Error & 2503.834 & 23 & 108.862 & & \\
\hline Total & 25755.592 & 26 & & & \\
\hline $\begin{array}{l}\text { Corrected } \\
\text { Total }\end{array}$ & 5153.782 & 25 & & & \\
\hline a. R Squared $=.514$ (Adjusted R Squared =.472) \\
\hline
\end{tabular}

\section{CONCLUSIONS}

Similar to the study conducted by Owens, the researchers for this study used the DIT-2 as the instrument of measure. Unlike the case of Owens, no statistically significant difference was noted between the treatment and control groups, thus the ethics instruction did not have a statistically significant effect on moral reasoning as measured by the DIT-2. One possible reason for this difference in results could be due to the inclusion of a control group in this study.

Any conclusions to be drawn from this study are subject to limitations encountered. First, small sample sizes for both groups coupled with attrition from the treatment group reduced the sample size even more. A smaller pool of participants was available due to an unanticipated lower enrollment during the time period set for the study. Also, as this study spanned only one semester with less than sixteen weeks between pre-test and post test, the results were then prone to test sensitization. Finally, as noted earlier, the DIT-2 measures only one component of moral conduct. While it is important to provide instruction that improves students' moral judgment, it is equally important to foster students' ability to recognize situations that call for ethical judgment.

There is a further issue concerning the appropriateness of the DIT-2 as an effective measure of discipline specific judgment. The true effect of an ethics course that is profession specific could be greater than the effect measured by the DIT-2. This 
suggests that it might be beneficial to develop a new instrument, perhaps modeled on the DIT-2, incorporating ethical dilemmas more particular to the field of Information Systems Technology (IST). This instrument could also incorporate Rest's Four Component Model [2] and the intermediate concepts of IST. Further, because discipline-specific judgment is bound together with sensitivity to ethical issues that may arise in professional practice, subsequent studies should include the development of a measure of ethical sensitivity tailored to the IST context.

Previous studies suggested that the effect of a single educational intervention on moral judgment may be short-lived [13]. For purposes of assessment, this suggests that a longitudinal study may be useful, in part, to determine to what extent a more sustained approach to ethics education could overcome the limitations of a single course or single instructional module. Perhaps more stringent empirical research approaches that use the most appropriate instruments for discipline-specific measures of growth in ethical reasoning will provide greater insight into this issue.

\section{REFRENCES}

1. Association for Computing Machinery. (1991, June). A Summary of the ACM/IEEE-CS Joint Curriculum Task Force Report. Computing Curricula 1991. Communications of the ACM, 34(6), p. 73.

2. Bebeau, J. M. (2002). The defining issues test and the four component model: Contributions to professional education. Journal of Moral Education, 31(3), 271-295.

3. Bebeau, J. M., \& Thoma, J. S. (1999). "Intermediate" concepts and the connection to moral education. Educational Psychology Review, 11(4), 343-360.

4. Drake, J. M., Griffin, M. P., Kirkman, R., \& Swann L. J. (2005). Engineering ethical curricula: Assessment and comparison of two approaches. Journal of Engineering Education, 40(2), 223-231.

5. Eigen, L. D. \& Siegal, J. P. (1989). The manager's book of quotations. New York, NY: AMAMCO

6. Hillier, P. (2003). The role of ethics in information security. ITAudit. Retrieved February 20, 2005, from http://www.theiia.org/itaudit/index.cfm?fuseacti on=print $\&$ fid $=5466$

7. Kohlberg, L. (1981). The philosophy of moral development, Vol.1. New York: Harper \& Row.

8. Owens, B. B. (2005). Student performance studying ethics in the context of Internet use. JCSC, 20(5), 285-294.

9. Rest, R. J., Thoma, J. S., Narvaez, D., \& Bebeau, J. M. (2000). A Neo-Kohlbergian approach to morality research. Journal of Moral Education, 29(4), 381-395.

10. Rest, J., Navarez, D.,Thoma, S. J. \& Bebeau, M (1999). DIT2: Devising and Testing a Revised Instrument of Moral Judgment . Journal of Educational Psychology, 91(4), 644-659.

11. Rest, J., Thoma, S. J., Narvaez, D. F., \& Bebeau, M. J. (1997). Alchemy and beyond: Indexing the defining issues test. Journal of Educational Psychology 89(3), 1 - 10.

12. Self, D.J., \& Ellison, E. (1998). Teaching Engineering Ethics: Assessment of Its Influence on Moral Reasoning Skills. Journal of Engineering Education, 87(1), 29-34.

13. Schlaefli, A., Rest, J., \& Thoma, S. (1985). Does moral education improve moral judgment? A meta-analysis of intervention studies using the defining issues test. Review of Education Research, 55(3), 319 - 352.

14. Walker, L. J. (1988). The development of moral reasoning. Annals of Child Development, 5, 3378. 